\title{
The Investigation of Savonius Type and Darrieus H Type Wind Turbine Simulation with Wind Speed Variable
}

\author{
Wibby Aditya Putra Utama1, Yohandri Bow ${ }^{2}$, M. Syahirman Yusi ${ }^{3}$ \\ ${ }^{1}$ Applied Master of Renewable Energy Engineering, Politeknik Negeri Sriwijaya, Jl. Srijaya Negara, \\ Palembang 30139, Indonesia \\ ${ }^{1}$ PT. Patra Selaras Sejati, Jl. Durian No. 319/09/10, Komperta Plaju, Palembang, Indonesia \\ ${ }^{2}$ Chemical Engineering Department, Energy Engineering Study Program, Politeknik Negeri Sriwijaya, Jl. \\ Srijaya Negara, Palembang, Indonesia \\ ${ }^{3}$ Business Administration Department, Politeknik Negeri Sriwijaya, Jl. Srijaya Negara, Palembang, Indonesia
}

\begin{tabular}{l}
\hline Article Info \\
\hline Article history: \\
Received July 11, 2021 \\
Revised August 10, 2021 \\
Accepted August 20, 2021 \\
\hline
\end{tabular}

Keywords:

Wind

Renewable

Energy

Savonius

Turbine

\begin{abstract}
The demand for electrical energy that continues to increase along with the advancement of civilization and also the increasing number of people as well as the reduced level of fulfillment and availability of non-renewable energy sources, it is necessary to have renewable energy resources that capable of fulfill these energy demand in a more environmental friendly. One of the natural energies that we can use is wind energy, which is easy to get and lasts continuously. This research examines the comparison of the power generated from the vertical axis wind turbine savonius type and darrieus $\mathrm{H}$ type. The wind that use in this research get from from the fan. The test is doing by varying the wind speed by adjusting the fan speed. The fan is directed to the wind turbine to rotate the wind turbine. To measure the wind speed produced by the fan, a digital anemometer is used. The result of this research is the relation data of voltage to rpm and voltage to wind speed of wind turbine.
\end{abstract}

This is an open access article under the CC BY-SA license.

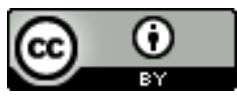

\section{Corresponding Author:}

Yohandri Bow

Chemical Engineering Departement, Energy Engineering Study Program

Politeknik Negeri Sriwijaya,

Jl. Srijaya Negara, Bukit Besar, Ilir Barat I, Palembang 30139, Indonesia

email: yohandri@polsri.ac.id

\section{INTRODUCTION}

The Fulfillment of electric energy for a variety of needs is still very dependent on non-renewable energy resources that are continues to decrease. The condition of energy resources, which are mostly nonrenewable, especially oil, is getting more and more limited. Because of that, the transition to renewable energy using is doing right now. There is a lot of choice of kind of renewable energy that available [1]. They are solar energy [2][21]-[23][25][26][28], wind energy [3][6]-[8][24][27][29], hydro energy, geothermal energy, biomass energy [4][5][30], tidal energy, etc. The application of renewable energy is depend on the renewable energy resouce that available on location [6].

Wind energy is a renewable energy that is very flexible [7][8]. Wind is air that moves due to differences of air pressure on the earth's surface. The wind will move from an area that has high pressure to an area that has a lower pressure. The difference of air pressure occurs due to differences in the reception of solar radiation. This wind movement has kinetic energy, therefore wind energy can be converted into other energy such as kinetic energy or electrical energy using windmills or wind turbines [9][10]. Wind turbines are windmills that are used to produce electricity [11]. Earlier, this wind turbine was created to accommodate the needs of farmers in carrying out rice milling, irrigation needs, etc. Previous wind turbines were built in Denmark, the Netherlands and other European countries and are better known as the Windmill. 
The wind turbine can be divided into two kinds, that is the horizontal axis wind turbine and the vertical axis wind turbine [12][13][14]. The horizontal axis wind turbine has a main rotor shaft and an electric generator at the top of the tower. Small turbines are directed by a simple tail vane, while large turbines generally use a wind sensor coupled to a servo motor. Most of horizontal axis wind turbine have a gearbox that converts a slow spinning wheel to a faster spin.

The vertical axis wind turbine has the main rotor shaft arranged perpendicularly. The main advantage of this arrangement is that the turbine does not have to be directed towards the wind to be effective [15]. This advantage is especially useful in places where the wind direction varies widely [16]. The vertical axis wind turbine is able to utilize the wind from various directions [17]. Because they are difficult to mount on top of a tower The vertical axis wind turbine are often mounted closer to the base on which they are placed, such as the ground or the top of a building's roof. Wind speeds are slower at lower altitudes, so there is less wind energy available. On this research we examines the comparison of the power generated from the Savonius type and Darrieus $\mathrm{H}$ type vertical axis wind turbines.

\section{RESEARCH METHOD}

Research in this study includes several stages. The flow chart in this final project research is presented in Figure 1.

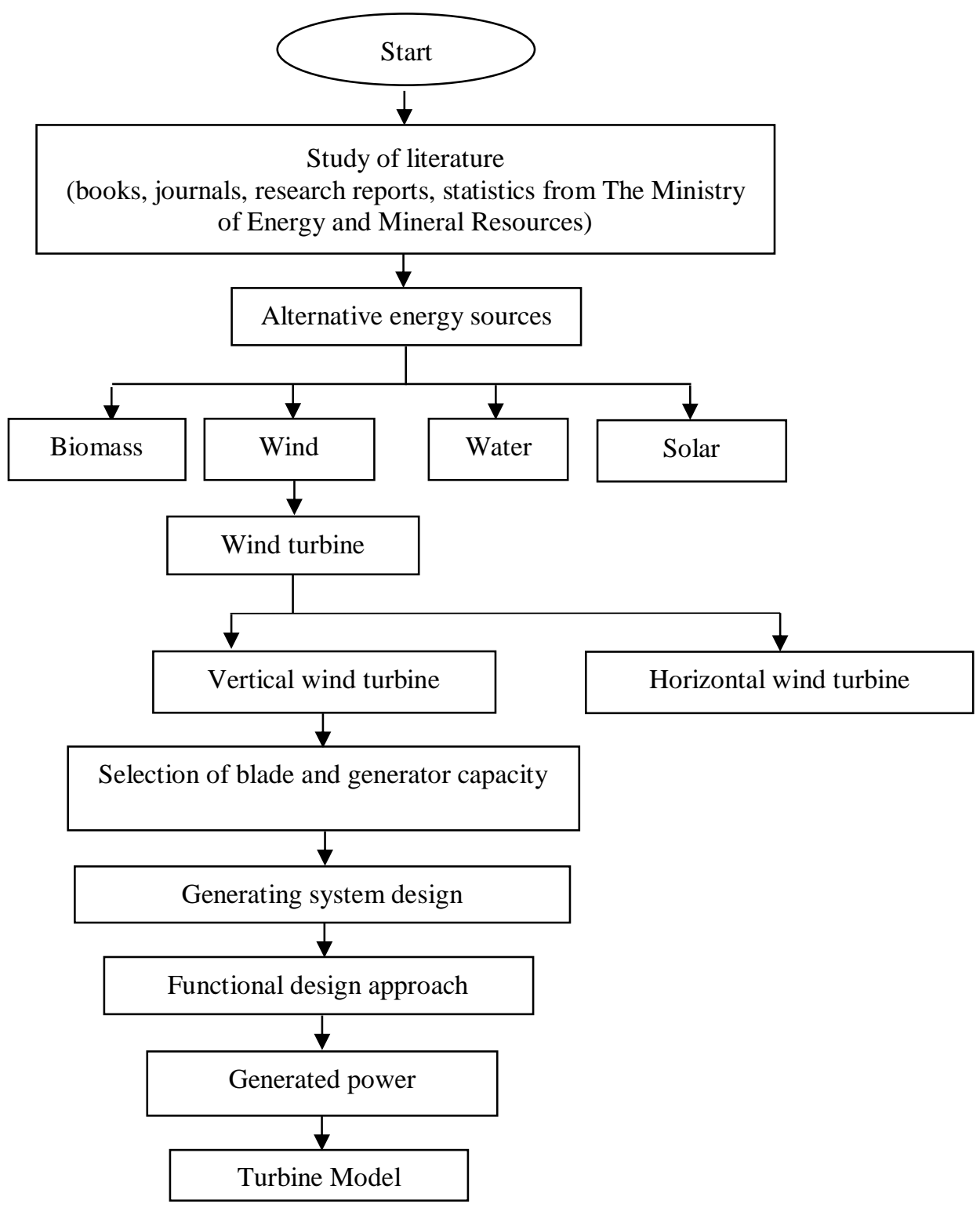

Figure 1. Research Framework 
For the making of the Savonius blade model [18], we use iron, fiber sheet and iron plate. The iron plate is bent to attach the fiber sheet so that it forms a concave area that receives the wind breeze. This is a design drawing and a finished Savonius blade turbine when place outdoor photo:

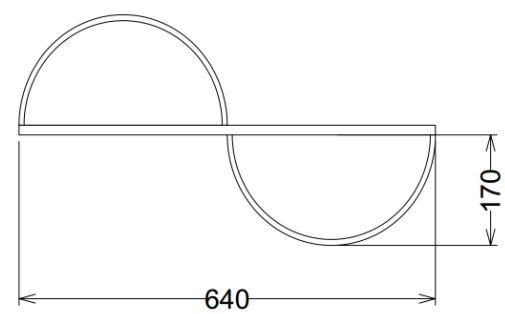

Scale in Milimeter

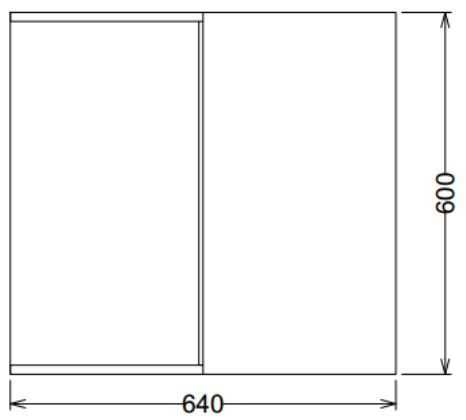

Scale in Milimeter

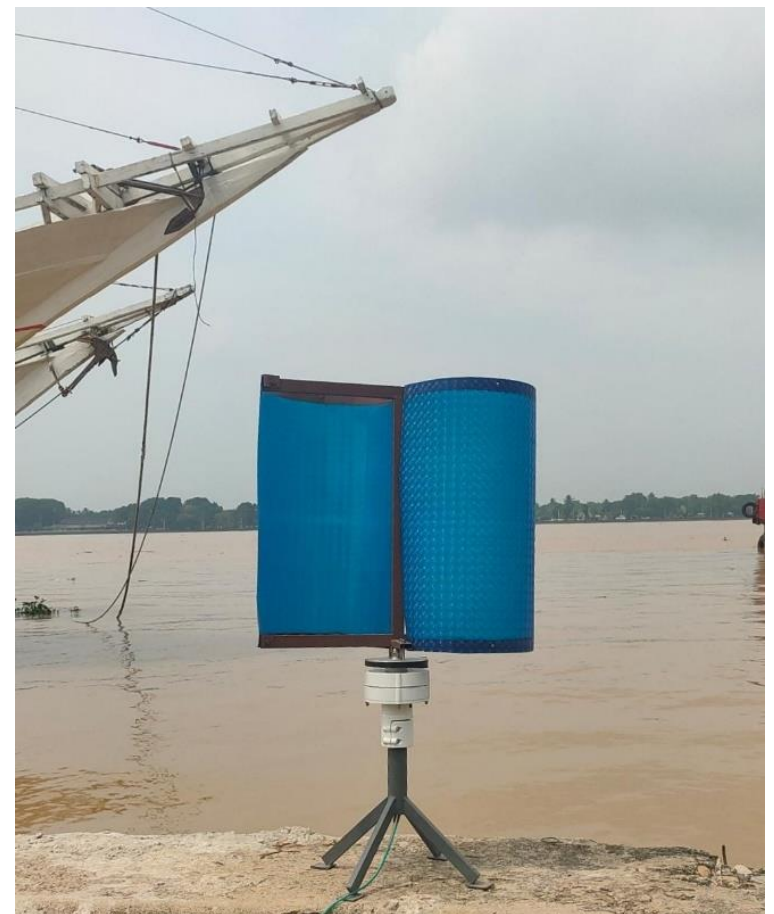

Figure 2. Savonius Blade Model

For the making of Darrieus H blade wind turbine, we use iron and 6 inch PVC pipe [19]. This is the design drawings and finished Darrieus H blade turbine when place outdoor photo:

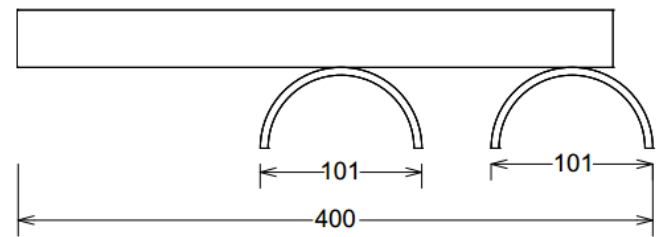

Scale in milimeter
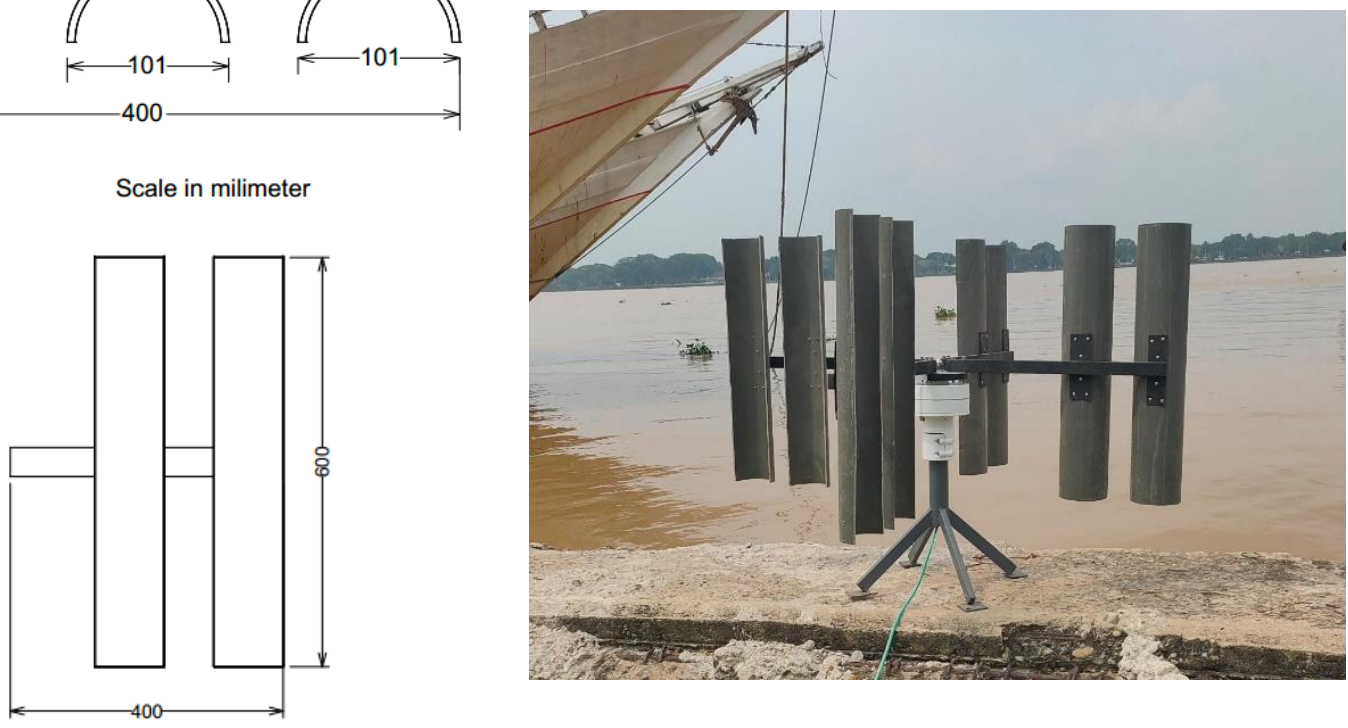

Scale in milimeter

Figure 3. Darrieus H Blade Model 
The reason of choosing the vertical axis wind turbine type is because the experiment is doing in Palembang, South Sumatera, Indonesia which don't have high wind speed. The vertical wind turbine type is recommended in low wind speed area because vertical axis wind turbine is able to utilize the wind from various directions so it can collect wind energy optimally in low wind speed area. The Savonius blade type and Darrieus blade type is most popular of vertical axis wind turbine. So hopefully the data result of this experiment can be use as consideration of choosing the type of vertical wind turbine in outdoor area in Palembang.

The experiment doing in indoor room to get the stability of wind velocity. The wind is generated by an electric fan [20]. The wind is directed by using a wind tunel which made of fiber sheets that are rolled into a tube. The speed of the wind coming out of the wind tunel is measured using an anemometer. After that the wind turbine is placed in the vent of the wind tunnel. The wind that comes out rotates the wind turbines. The output produced by wind turbines is measured using a multimeter. Experiment was done by varying 3 electric fan speeds, resulting in 3 variations of wind speed $(4.8 \mathrm{~m} / \mathrm{s}, 4.9 \mathrm{~m} / \mathrm{s}$ and $5.3 \mathrm{~m} / \mathrm{s})$. For each wind speed, the wind speed is measured with anemometer and the electricity output is generated using a multimeter. For rpm measurement its use tachometer. This method does for each wind turbine models (savonius wind turbine and darrieus $\mathrm{H}$ wind turbine).

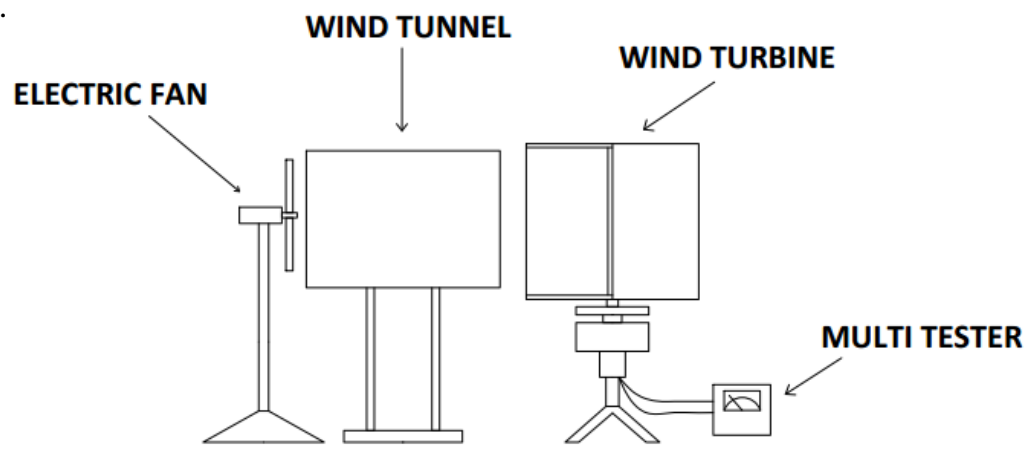

Figure 4. The Position of The Equipment When Data Collection Process

\section{RESULTS AND DISCUSSION}

In this research, to get the wind speed, the wind from the fan is used. The test is doing by varying the wind speed by adjusting the fan speed. The fan is directed to the wind turbine to rotate the wind turbine. To measure the wind speed produced by the fan we use a digital anemometer. The variation in wind speed that results in a fan is $4.8 \mathrm{~m} / \mathrm{s}, 4.9 \mathrm{~m} / \mathrm{s}$ and $5.3 \mathrm{~m} / \mathrm{s}$. Testing is doing with the wind speed variation on the two models blade turbine which is Savonius blade wind turbine and Darrieus H blade wind turbine.

\subsection{Testing of the Savonius Model Wind Turbine}

Test data for the Savonius wind turbine:

Table 1. Savonius Wind Turbine Data

\begin{tabular}{ccc}
\hline $\begin{array}{c}\text { Wind Speed } \\
(\mathrm{m} / \mathrm{s})\end{array}$ & $\begin{array}{c}\text { Rotation per Minutes } \\
(\mathrm{rpm})\end{array}$ & $\begin{array}{c}\text { Voltage } \\
(\text { Volt })\end{array}$ \\
\hline 4.8 & 57.9 & 7.37 \\
4.9 & 58.6 & 8.14 \\
5.3 & 63.4 & 8.2 \\
\hline
\end{tabular}

\subsection{Testing of the Darrieus $H$ Model Wind Turbine}

Test data for the Darrieus H wind turbine:

Table 2. Darrieus H Wind Turbine Data

\begin{tabular}{ccc}
\hline $\begin{array}{c}\text { Wind Speed } \\
(\mathrm{m} / \mathrm{s})\end{array}$ & $\begin{array}{c}\text { Rotation per Minutes } \\
(\mathrm{rpm})\end{array}$ & $\begin{array}{c}\text { Voltage } \\
(\text { Volt })\end{array}$ \\
\hline 4.8 & 47.1 & 3 \\
4.9 & 49.5 & 3.14 \\
5.3 & 51.2 & 3.6 \\
\hline
\end{tabular}




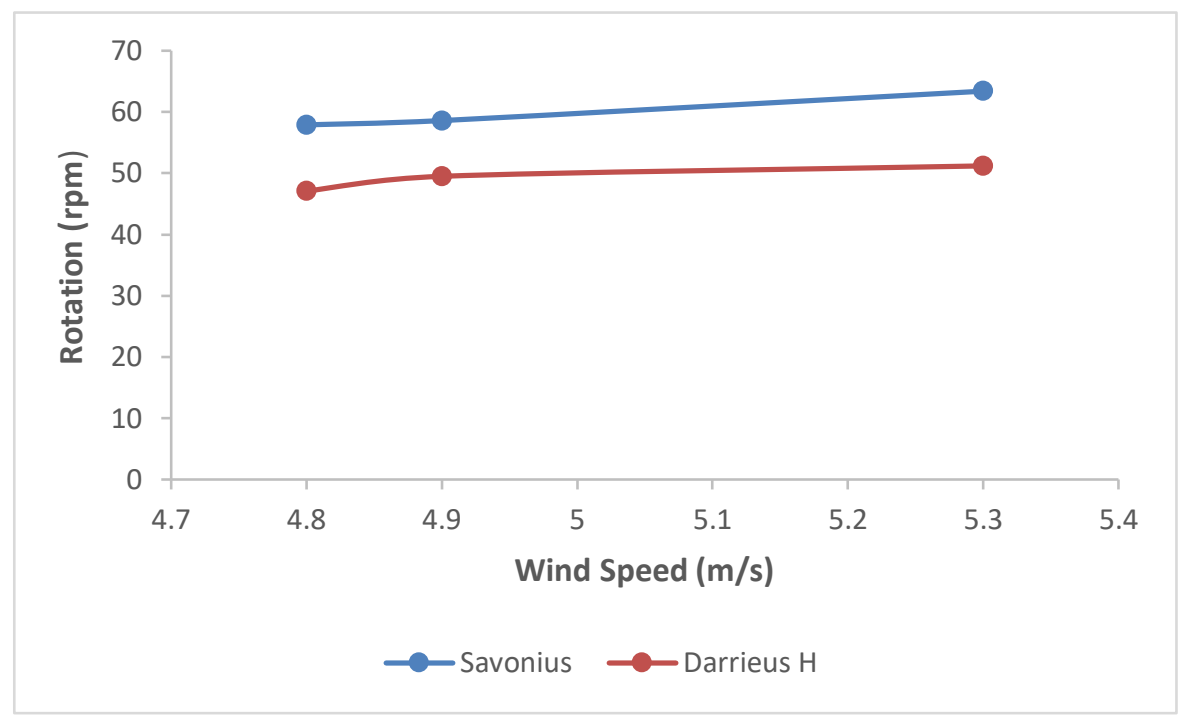

Figure 5. Graph of Rotation (rpm) to Wind Speed (m/s) of the Savonius Turbine Model and the Darrieus H Turbine Model

Figure 5 is graph of voltage (Volt) to rotation (rpm) of the Savonius turbine model and the Darrieus $\mathrm{H}$ turbine model The blue color graph is the graph for the Savonius blade wind turbine. The greater the wind speed, the greater the rotational speed produced. In the wind speed range of $4.8-5.3 \mathrm{~m} / \mathrm{s}$ the Savonius wind turbine model produces rotational speed of $57.9-63.4 \mathrm{rpm}$. Meanwhile, the orange color graph is the graph for the Darrieus H blade wind turbine. The greater the wind speed, the greater the rotational speed produced. In the wind speed range of $4.8-5.3 \mathrm{~m} / \mathrm{s}$ the Darrieus $\mathrm{H}$ wind turbine model produces rotational speed of 47.1 - $51.2 \mathrm{rpm}$. From the Graph of Voltage (Volt) to Rotation Speed (rpm) of the Savonius Turbine Model and the Darrieus H Turbine Model, the highest rpm measurement results were obtained for the Savonius turbine model which is $63.4 \mathrm{rpm}$ at a wind speed of $5.3 \mathrm{~m} / \mathrm{s}$.

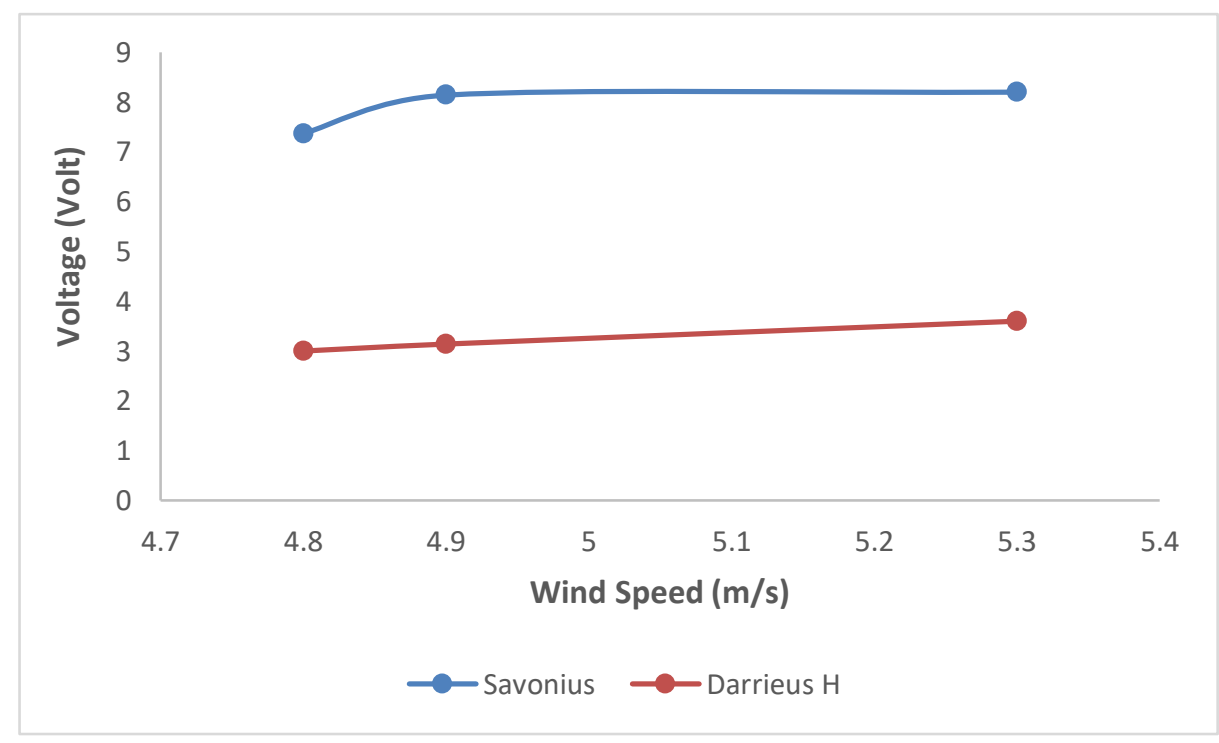

Figure 6. Graph of Voltage (Volt) to Wind Speed $(\mathrm{m} / \mathrm{s})$ of the Savonius Turbine Model and the Darrieus H Turbine Model

Figure 6 is graph of voltage (Volt) to wind speed $(\mathrm{m} / \mathrm{s})$ of the Savonius turbine model and the Darrieus H turbine model. The blue color graph is the graph for the Savonius blade wind turbine. The greater 
the wind speed, the greater the voltage generated.In the wind speed range of $4.8-5.3 \mathrm{~m} / \mathrm{s}$ the Savonius wind turbine model produces a rotational speed of voltage of $7.37-8.2$ volts. Meanwhile, the orange color graph is the graph for the Darrieus H blade wind turbine. The greater the wind speed, the greater the voltage generated. In the wind speed range of $4.8-5.3 \mathrm{~m} / \mathrm{s}$ the Darrieus $\mathrm{H}$ wind turbine model produces voltage of 3 - 3.6 volts. From the graph of voltage (Volt) to wind speed $(\mathrm{m} / \mathrm{s})$ for the Savonius turbine model and the Darrieus $\mathrm{H}$ turbine model, the highest voltage measurement results in the Savonius turbine model which is $8.2 \mathrm{~V}$ at a wind speed of $5.3 \mathrm{~m} / \mathrm{s}$.

\section{CONCLUSION}

From the research that has been done, the Savonius and Darrieus $\mathrm{H}$ turbines are able to rotate at wind speeds of $4.8-5.3 \mathrm{~m} / \mathrm{s}$ (which is include as gentle brezze category) which is this wind speed is produced by a electric fan. Both types of turbines are capable of rotating to generate electricity. In the wind speed range of $4.8-5.3 \mathrm{~m} / \mathrm{s}$ the Savonius wind turbine model produces rotational speed of 57.9-63.4 rpm and voltage of $7.37-8.2$ volts. In the wind speed range of $4.8-5.3 \mathrm{~m} / \mathrm{s}$ the Darrieus $\mathrm{H}$ wind turbine model produces rotational speed of 47.1-51.2 rpm and voltage of 3 - 3.6 volts.

In this experiment, the Savonius turbine is able to produce more electricity than the Darrieus $\mathrm{H}$ model. This is due to the wider blade area so that it is able to capture more wind and produce rotating power from a wind speed. However, it should be noted that because it captures more wind, the Savonius model will be more susceptible to high wind speeds that can exceed the mechanical limits of the blade and turbine itself. While the Darrieus H model is more resistant to higher wind speeds because the blade surface is not as wide as the Savonius model. The use of the model choice depends on the wind conditions where the turbine will be installed._At low wind speeds area and there is no high wind speed, the Savonius model is recommended.

\section{ACKNOWLEDGEMENT}

Many thanks to Applied Master of Renewable Energy Engineering Politeknik Negeri Sriwijaya, Palembang, Indonesia.

\section{REFERENCES}

[1] R. Ploetz, Rusdianasari, and Eviliana, "Renewable Energy: Advantages and Disadvantages," Proceeding Forum Res. Sci. Technol. 2016, vol. Vol. 3, no. Issue 1, pp. 1-4, 2016.

[2] A. Kurniawan, A. Taqwa, and Y. Bow, "PLC Application as an Automatic Transfer Switch for on-grid PV System; Case Study Jakabaring Solar Power Plant Palembang," J. Phys. Conf. Ser., vol. 1167, no. 1, 2019, doi: 10.1088/1742-6596/1167/1/012026.

[3] Marco Casini, "Small Vertical Axis Wind Turbines for Energy Efficiency of Buildings," J. Clean Energy Technol., vol. 4, no. 1, pp. 56-65, 2015, doi: 10.7763/jocet.2016.v4.254.

[4] Y. Bow, L. Kalsum, A. Hasan, A. Husaini and Rusdianasari, "The Purification of Biogas with Monoethanolamine ( MEA ) Solution Based on Biogas Flow Rate," " Proceedings of the 4th Forum in Research, Science, and Technology (FIRST-T1-T2-2020), vol. 7, pp. 12-17, 2021.

[5] Rusdianasari, A. Syarif, M. Yerizam, M. S. Yusi, L. Kalsum, and Y. Bow, "Effect of Catalysts on the Quality of Biodiesel from Waste Cooking Oil by Induction Heating," J. Phys. Conf. Ser., vol. 1500, no. 1, 2020, doi: 10.1088/1742-6596/1500/1/012052.

[6] A. Susandi, F. Arifin, and Rusdianasari, "Simulation of Diffuser Parameters in the Performance of Horizontal Axis Wind Turbine using Computational Fluid Dynamics”, Technology Reports of Kansai University, Vol. 63(06), 2021.

[7] A. Taqwa, Rusdianasari, Budiman, R. D. Kusumato, and T. Dewi, "Synchronization and Application of IoT for on Grid Hybrid PV-Wind System,” Proc. - 2018 Int. Conf. Appl. Sci. Technol. iCAST 2018, no. 2, pp. 617-621, 2018, doi: 10.1109/iCAST1.2018.8751532.

[8] R.B. Yuliandi, Rusdianasari, and T.Dewi, "Comparison of Blade Dimension Design of a Vertical Wind Turbine Applied in Low Wind Speed,” E3S Web Conf., vol. 68, pp. 1-6, 2018, doi: 10.1051/e3sconf/20186801001.

[9] Md Mehedi Hasan, "Design and Performance Analysis of Small Scale Horizontal Axis Wind Turbine for Nano Grid Application," 2017, [Online]. Available: https://digitalcommons.georgiasouthern.edu/etd/1605.

[10] Bavin Loganathan, Harun Chowdhury, Israt Mustary, Md Masud Rana, and Firoz Alam, "Design of a micro wind turbine and its economic feasibility study for residental power generation in built-up areas," Energy Procedia, vol. 160, no. 2018, pp. 812-819, 2019, doi: 10.1016/j.egypro.2019.02.153.

[11] A. Maideen Abdhulkader Jeylani, A. Mahaboob, G. Radhakrishnan, and K. Rameshkumar, "Design and Anaysis of Small- Scale Wind Turbine," Int. J. Pure Appl. Math., vol. 119, no. 12, pp. 1817-1828, 2018.

[12] Deibanehbok Nongdhar, Bikramjit Goswami, Pallav Gogoi, and Sidharth Borkataky, "Design of Horizontal Axis Micro Wind Turbine for Low Wind Speed Areas," ADBU J. Electr. Electron. Eng., vol. 2, no. 2, pp. 39-47, 2018, [Online]. Available: www.tinyurl.com/ajeee-adbu.

[13] Deibanehbok Nongdhar and Bikramjit Goswami, "Design of Micro Wind Turbine for Low Wind Speed Areas: A Review," $A D B U$ J. Electr. Electron. Eng., vol. 2, no. 2, pp. 39-47, 2018, [Online]. Available: www.tinyurl.com/ajeee-adbu. 
[14] Zheng Li, Ruihua Han, Peifeng Gao, and Caisheng Wang, "Analysis and implementation of a drag-type verticalaxis wind turbine for small distributed wind energy systems," Adv. Mech. Eng., vol. 11, no. 1, pp. 1-16, 2019, doi: $10.1177 / 1687814019825709$.

[15] B. Rapelli, Rajnikant T Suryavanshi, Mahesh L Shelke, Shweta G Patil and Pratik Tikar, "Design and Development of Foldable and Portable Windmill," pp. 3084-3094, 2017.

[16] N. A. Nader and A. Jendoubi, "Study of a vertical axis wind turbine for low speed regions in Saudi Arabia," Int. Conf. Fluid Flow, Heat Mass Transf., no. 139, p. 139, 2018, doi: 10.11159/ffhmt18.139.

[17] P. Pathike, T. Katpradit, P. Terdtoon, and P. Sakulchangsatjatai, "Small horizontal-axis wind turbine blade for low wind speed operation,” J. Appl. Sci. Eng., vol. 16, no. 4, pp. 345-351, 2013, doi: 10.6180/jase.2013.16.4.02.

[18] Ozkar F. Homzah, Tri Widagdo, Mardiana Ibnu, and Asrofi Destra, "Prototype of Small Savonius Wind Turbine," vol. 7, pp. 208-213, 2021.

[19] Vicky K. Rathod and Prof.S.Y Kamdi, "Design \& Fabrication of PVC Bladed Inexpensive Wind Turbine," IOSR J. Mech. Civ. Eng., vol. 11, no. 4, pp. 114-119, 2014, doi: 10.9790/1684-1142114119.

[20] Josué Njock Libii and David M. Drahozal, "Use of a miniature wind turbine with rectangular blades to demonstrate and confirm the existence of optimal angles of inclination of turbine blades at which peak power is produced," World Trans. Eng. Technol. Educ., vol. 10, no. 1, pp. 35-40, 2012.

[21] Y. Bow, A. Syakdani, M. Taufik, and Rusdianasari, "Effect of Drying Ariflow Rate on $\mathrm{H}_{2} \mathrm{O}$ Mass Evaporated on Banana Chips Drying using Photovoltaic Solar Panel”, J. Phys.: Conf. Ser. 1500 012015, 2020.

[22] N. Pasaribu, Rusdianasari, and A. Syarif, "Efficiency of 9Kwp Sun Tracking Photovoltaic in Palembang, Indonesia”, IOP Conf. Ser.: Earth Environ. Sci. 347 012129, 2019.

[23] H. Wibowo, Y. Bow, and CR. Sitompul, "Performance Comparison Analysis of Fixed and Solar-Tracker Installed Panel at PV System", IOP Conf. Ser.: Earth Environ. Sci. 709 012003, 2021.

[24] A. Garmana, F. Arifin, and Rusdianasari, "CFD Analysis for Combination Savonius and Darrieus Turbine with Differences in the Number of Savonius Turbine Blades", 2021 International Conference on Artificial Intelligence and Mechatronics System (AIMS), IEEE, 2021.

[25] Mirdiansyah, A. Taqwa, Y. Bow. "Monitoring Depth of Discharge of a Valve Regulated Lead Acid Battery in a Standalone PV System," Proceedings of the 4th Forum in Research, Science, and Technology (FIRST-T1-T22020), 2021.

[26] Y Bow, T Dewi, A Taqwa, Rusdianasari, Zulkarnain, "Power Transistor 2N3055 as a Solar Cell Device," International Conference on Electrical Engineering and Computer Science (ICECOS), IEEE, 2018.

[27] A. Taqwa, R. Rusdianasari, Budiman, RD. Kusumanto, T. Dewi, "Synchronization and application of IoT for on grid hybrid PV-wind system," International Conference on Applied Science and Technology (iCAST) IEEE 617$621,2018$.

[28] S Widodo, A Taqwa and R Rusdianasari, "Solar panels output optimization using Phase Change Material (PCM) and heatsink applied in open-pit mining," IOP Conf. Series: Materials Science and Engineering 1073 (2021) 012041, 2021.

[29] C. Sovanara, F. Firdaus, R. Rusdianasari, "A Review on environmental impact of wind energy," in Proceeding Forum in Research, Science, and Technology (FIRST), 2016.

[30] Y. Bow, E. Effendi, A. Taqwa, G. Rinditya, M.Y. Pratama, and Rusdianasari, "Analysis of Air Fuel Ratio on Combustion Flames of Mixture Waste Cooking Oil and Diesel using Preheating Method", IOP Conf. Ser.: Earth Environ. Sci. 709 012004, 2021.

\section{BIOGRAPHIES OF AUTHORS}

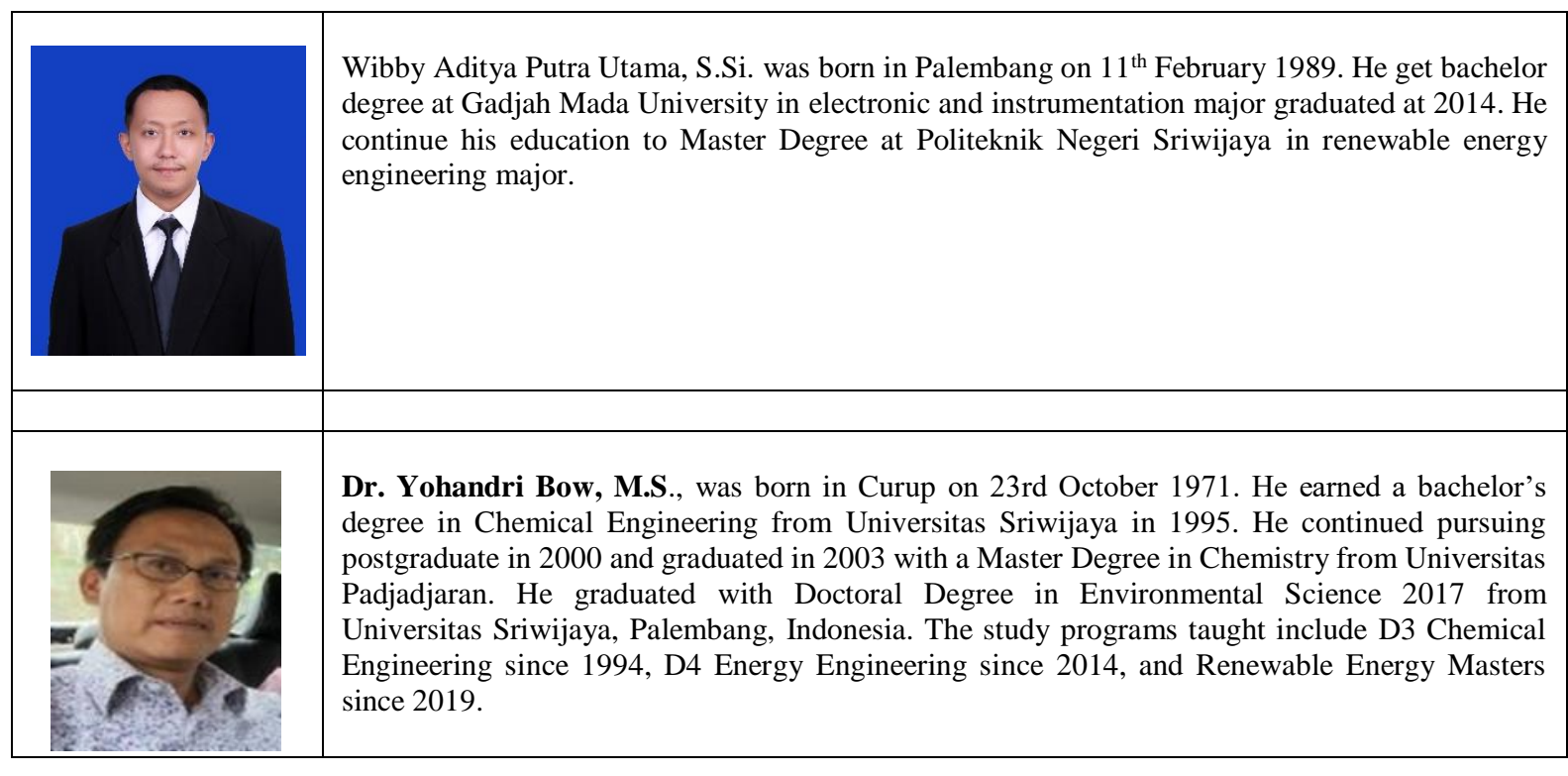

Title of manuscript is short and clear, implies research results (First Author) 


\begin{tabular}{|l|l|}
\hline & $\begin{array}{l}\text { Dr. M. Syahirman Yusi, M.S., was born in Palembang on 17th August 1958. He got bachelor } \\
\text { degree at University of Sriwijaya in Economics mayor graduated at 1984. Postgraduate } \\
\text { Economics field (S-2) on1990 with Masters in Management at University of Padjadjaran. } \\
\text { Graduated from Doctoral Agricultural Management Science on 2007 at Univeristy of Sriwijaya } \\
\text { Palembang. }\end{array}$ \\
\hline
\end{tabular}

